\title{
Static and dynamic analytical and experimental analysis of 3D reinforced concrete panels
}

\author{
K. Numayr \& R. Haddad \\ Civil Engineering Department, \\ Jordan University of Science and Technology, Irbid, Jordan
}

\begin{abstract}
A three-dimensional panel system, which was offered as a new method for construction in Jordan using relatively high strength modular panels for walls and ceilings, is investigated in this paper. The panel consists of two steel meshes on both sides of an expanded polystyrene core and connected together with a truss wire to provide a 3D system. The top face of the ceiling panel was pored with regular concrete mix, while the bottom face and both faces of the wall panels were cast by shotcreting (dry process). To investigate the structural performance of this system, an extensive experimental testing program for ceiling and wall panels subjected to static and dynamic loadings was conducted. The load-deflection curves were obtained for beam and shear wall elements and wall elements under transverse and axial loads, respectively. Static and dynamic analyses were conducted, and the performance of the proposed structural system was evaluated and compared with a typical three dimensional reinforced concrete frame system for buildings of the same floor areas and number of floors. Compressive strength capacity of a ceiling panel is determined for gravity loads, while flexural capacity is determined under the effect of wind and seismic loading. It was found that the strength and serviceability requirements could be easily satisfied for buildings constructed using the three-dimensional panel system. The 3D panel system is superior to that of conventional frame system in its dynamic performance, due to its high stiffness to mass ratio.

Keywords: three-dimensional, panel, static, dynamic, concrete, shotcrete, gravity, wind, seismic load.
\end{abstract}




\section{Introduction}

The structural systems adopted since the beginning of this century were based on either skeleton and/or shear wall systems, both proved to provide safety and integrity for the constructed facilities [1]. However, the former is more popular and usually constructed using one or two of the materials, steel, wood, and/or concrete. The use of any of these materials depends on its availability, seismic activity of the region where the structure is to be built, and the dominant weather conditions. This is why, wood and steel are mostly used in the construction industry in the United States, and Europe, whereas, reinforced concrete is extensively used in the Middle East and the rest of the third world countries.

Construction using the above materials and structural systems requires considerable time and is relatively expensive, especially for low-income people. To overcome this, new alternative systems and/or construction techniques were proposed to cut down both construction cost and time. Reinforced concrete panels [2-4], precast shear walls [5-6], and pre-stressed beams, and slabs [7], were used to reduce construction time, as well as construction cost especially in large projects that demands massive production of these elements. In addition, owing to better quality control during concrete casting these elements would be stronger and more durable than those cast on site. Nevertheless, the spreads of poverty, especially in the third world countries demand safe, serviceable, and low cost construction systems. This had researchers and engineers search for innovative ideas to deal with the problem. In Jordan, for example, low-income housing was established on using cheap local construction materials, blocks and reinforced concrete, to construct small units. Yet, these units failed in providing safety and serviceability. Therefore, the government demolished high percentage of these units although were in service for less than twenty years.

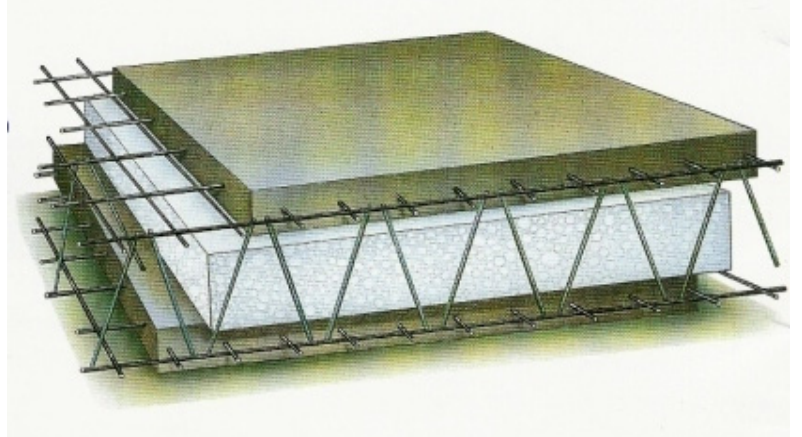

Figure 1: Typical panel showing steel meshes in concrete layers, steel truss, and polystyrene core.

Recently, a three-dimensional system was offered as a new method for construction using relatively high strength modular panels for walls and ceilings. These consist of two steel meshes on both sides of an expanded polystyrene core 
and connected together with a truss wire to provide a three-dimensional system. Details of typical ceiling and wall panels are shown in Fig. 1. To investigate the structural performance of this system, an extensive experimental testing program for ceiling and wall panels was conducted. This included, two points loading of ceiling and wall beams, one and two points loading of shear wall elements, and axially distributed loading of shear wall elements. The load-deflection curves were obtained, through measuring the mid-span deflection (for beam panels) and mid-span and lateral deflections for shear wall panel elements loaded axially. Both static and dynamic analyses were conducted, and the dynamic performance of the proposed structural system was evaluated and was compared with that of a typical skeleton system, both used to construct similar floor numbers and areas.

\section{Static and dynamic analysis}

Static and dynamic analysis were performed for wall and the ceiling panels in a shear building with floor area of $256 \mathrm{~m}^{2}$ as shown in Fig. 2. The dead load on each floor is estimated based on the assumption that the following materials exist over the ceiling panel: tiles of $25 \mathrm{~mm}$, cement mortar of $25 \mathrm{~mm}$, and sand layer of $50 \mathrm{~mm}$. Hence, the overall deal load was found to be $4.3 \mathrm{kN} / \mathrm{m}^{2}$. A live load of $1.96 \mathrm{kN} / \mathrm{m}^{2}$ for private residents is used. The own weight of a wall panel is found to be $1.96 \mathrm{kN} / \mathrm{m}^{2}$. The top part of the ceiling panel was cast using $60 \mathrm{~mm}$ relatively low slump concrete, which was consolidated by rodding, while the bottom part of ceiling panel of $45 \mathrm{~mm}$ thickness and both layers of the wall panels of about $40 \mathrm{~mm}$ thickness were cast by shotcreting (dry process). Concrete strengths $\left(f^{\prime} \mathrm{c}\right)$ for regular and shotcrete concretes were, conservatively, assumed to be about $25 \mathrm{MPa}$, and $17 \mathrm{MPa}$, respectively. The steel yielding strength $\left(f_{\mathrm{y}}\right)$ was assumed of about $414 \mathrm{MPa}$. The moduli of elasticity for steel and concrete are $\mathrm{Es}=200000 \mathrm{MPa}$, and $E_{c}=4700 \sqrt{f_{c}} \mathrm{MPa}$, respectively.

The structural capacities of the ceiling and the wall panels are determined according to the design methods specified in the American Concrete Institute "Building Code Requirements for Reinforced Concrete ACI 318," [8]. Flexural and shear capacity, in addition to deflection, of ceiling panel is calculated under the effect of gravity loads for a typical $4 \mathrm{~m} \times 4 \mathrm{~m}$ slab in a residential building. For a wall panel, the compressive capacity is determined for gravity loads, while flexural capacity is determined under the effect of a uniformly distributed wind load of $1 \mathrm{kN} / \mathrm{m}^{2}$. Both the ceiling and wall panels are assumed, conservatively, simply supported. The calculated external moment, shear, and/or thrust loads for ceiling and/or wall panels are listed in Table 1. Also the moment, shear, and/or thrust structural capacity of a one meter-width cross section for the ceiling panels are listed in Table 1. The deflection of a ceiling panel is calculated and compared to experimental and the allowable values.

The dynamic analysis was carried out on the two systems shown in Fig. 2, namely, the panel-supported floor Fig. 2(a), and skeleton-supported floor Fig. 2(b). The dynamic analysis for one, three and seven story shear buildings was carried out and the results are listed in Table 2. In the dynamic analysis of 
the 3-D system, three case were considered: a) lateral walls only; b) longitudinal walls only; and c) both longitudinal and lateral walls. The analysis of the seven floor system was carried out considering single panels or double panels for the walls of the lower three floors. In analyzing the skeleton-supported floor system, the columns were assumed to be $300 \times 300 \mathrm{~mm}$, reinforced with $8 \phi 14 \mathrm{~mm}$ rebars with $2 \phi 10 \mathrm{~mm}$ ties spaced at $200 \mathrm{~mm}$. The overall calculated dead load is $900 \mathrm{~kg} / \mathrm{m}^{2}$ plus a live load of $200 \mathrm{~kg} / \mathrm{m}^{2}$ were considered in the calculation of the lump masses.

\section{Experimental evaluation of the 3D system}

\subsection{Materials}

Pozzolanic Portland cement, manufactured by Jordan Cement Factory, limestone crushed course and fine aggregate, and natural sand were used to prepare concrete mixture used to cast the top layer of the slab panel. The bottom layer of slab panels and both layers of wall panels were shotcreted using a concrete mixture prepared using the same above cement with a mixture of crushed limestone fine aggregate and natural sand (Suweileh sand) at mass ratio of 2:1. The gradations of coarse limestone aggregate and the mixture of fine limestone and the natural sand were proportioned so as to meet the ASTM requirements [9]. The (specific gravity (SSD) and absorption) of coarse limestone aggregate, fine limestone aggregate, and natural sand were determined according to the ASTM test methods C 127 and 128 [9]. These were found to be (2.61, and 1\%), $(2.54,4 \%),(2.6,0.8 \%)$, respectively. The compacted and loose unit weights of coarse limestone aggregate, determined according to ASTM test method C 29 [9], were $1540,1320 \mathrm{~kg} / \mathrm{m}^{3}$, respectively.

\subsection{Concrete mix design}

The American Concrete Institute (ACI 211.1) method of mix design for normal weight concrete was used to proportion the concrete mixture, [8]. The cylinder specified strength was $30 \mathrm{MPa}$ at 28-days, which is equivalent to cube strength of $38 \mathrm{MPa}$. The margin of strength taken in the design of the concrete mixes was chosen so that the proportion of strengths less than the specified strength is less than $5 \%$ and that the standard deviation used to determine the margin is assumed to be 4.0 MPa. Therefore a target strength of $44.6 \mathrm{MPa}$ was used in the mix proportioning. The shotcrete mixture was proportioned at cement to fine particles mass ratio of 1 to 5 , respectively.

\subsection{Panels casting and concrete strength evaluation}

The slab panels were placed horizontally. Then, the top layer was cast using regular concrete, during which the concrete was consolidated by an electric vibrator. After that, the bottom layer was cast by shotcreting (dry process) using the mix specified for this procedure. As for the wall panels, both layers were shotcreted after the panel was positioned vertically. The panels were covered by 
burlap and were keep moist until time of testing. Six standard cube specimens $(150 \mathrm{~mm})$ were cast from the concrete mix to obtain the compressive strength at 28 days of curing. Cores were obtained from a special panel $(0.6 \times 1 \times 0.1 \mathrm{~m})$, fabricated and cast from the same shotcrete mix and cured for 28 days, were tested for compressive strength. Other cores were obtained from the top layer of slab panel after being cured for 28 days. The compressive strength for concrete cubes averaged 43.4 $\mathrm{MPa}$, whereas equivalent cube strength of obtained cores averaged $19 \mathrm{MPa}$.

(a)

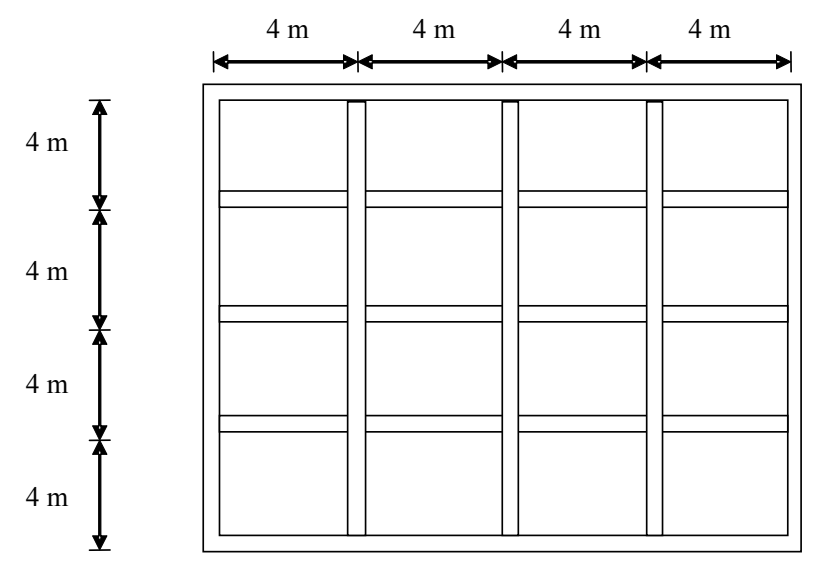

(b)

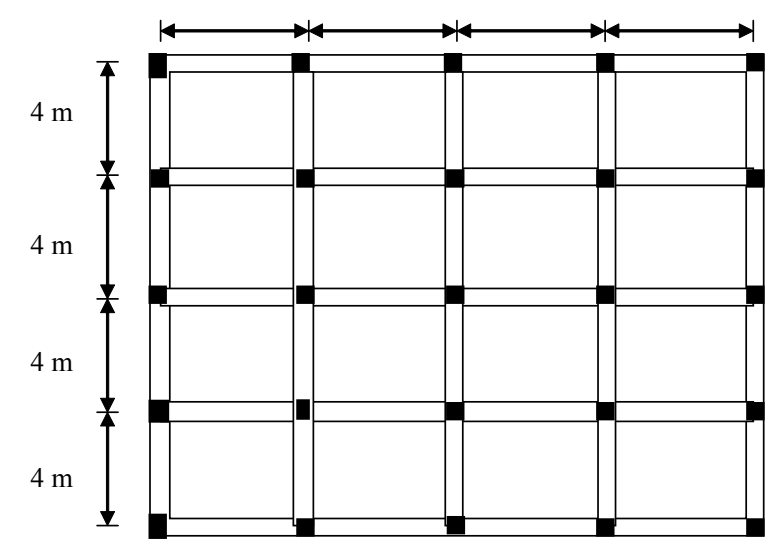

Figure 2: $\quad$ Floor plans for (a) 3-D panel system, (b) skeleton system.

\section{Summary and discussion of results}

A summary of the results of the static and dynamic analysis in addition to the experimental ones is presented herein to give a better insight of the structural 
performance of the 3-D system compared to the traditional skeleton system. Table 1 presents ultimate and reduced nominal capacity values of ceiling panel subjected to transverse gravity loads. It also presents ultimate and reduced nominal axial load capacity of a wall panel. The ceiling panel satisfies shear requirement $\left(\mathrm{V}_{\mathrm{u}}<\phi \mathrm{V}_{\mathrm{n}}\right)$ as part of one or two way slabs. It doesn't satisfy moment $\left(\mathrm{M}_{\mathrm{u}}<\phi \mathrm{M}_{\mathrm{n}}\right)$ as part of one way slab, and therefore the section needs modification, for instance increasing the area of steel or the depth of the section. It satisfies serviceability requirement for deflection. This suggests that the ceiling panel cannot be used with unsupported length of $4.0 \mathrm{~m}$ as a part of one-way slab. The maximum unsupported length for the panel to be used in one way slab so that the section moment capacity is not exceeded is found to be about $2.7 \mathrm{~m}$. The thrust, and moment capacity of the wall panels are much higher than external thrust, and moment, respectively. This indicates that the proposed wall panels as high as $3 \mathrm{~m}$ and that the two-way ceiling panels spanned as long as $4 \mathrm{~m}$ can be used with a high margin of safety.

Table 1: $\quad$ Static analysis of ceiling and wall panels of the 3DS.

\begin{tabular}{|l|l|l|l|l|l|l|l|}
\hline \multirow{3}{*}{$\begin{array}{c}\text { Panel } \\
\text { Type }\end{array}$} & & \multicolumn{3}{|c|}{ Calculated } & \multicolumn{3}{c|}{ Allowable } \\
\cline { 3 - 8 } & Type & $\begin{array}{l}\mathrm{Mu} \\
(\mathrm{kN} . \mathrm{m})\end{array}$ & $\begin{array}{l}\text { ULC } \\
(\mathrm{kN})\end{array}$ & $\delta(\mathrm{m})$ & $\begin{array}{l}\phi \mathrm{Mn} \\
(\mathrm{kN} . \mathrm{m})\end{array}$ & $\begin{array}{c}\text { ULC } \\
(\mathrm{kN})\end{array}$ & $\delta(\mathrm{m})$ \\
\hline \multirow{2}{*}{$\mathrm{CP}$} & OWS & 18.76 & 18.76 & 0.0123 & 9.32 & 54.1 & 0.017 \\
\cline { 2 - 8 } & TWS & 5.40 & 9.38 & 0.0062 & 9.32 & 54.1 & 0.017 \\
\hline WP & NA & 1.46 & 111.4 & NA & 8.32 & 711 & NA \\
\hline
\end{tabular}

ULC: Shear for ceiling and axial force for wall panels; $\delta$ : deflection; OWS: one-way slab; TWS: two-way slab; NA: not applicable.

For a one-story shear building, the lumped mass of one typical panel, one continues wall and ceiling through the building, which includes half the mass of nine wall panels of $(4 \mathrm{~m})$ long each and $(3 \mathrm{~m})$ high in addition to the dead load and live load masses of four ceiling panels, $(4 \mathrm{mx} 4 \mathrm{~m})$ each excluding openings of windows and doors in interior and exterior walls is about 50 tons compared to that of the skeleton system of about 70 tons. The natural frequency is about 6.15 radians/sec when considering lateral walls only.

From response spectra of elastic system for 1940 El Centro earthquake, assuming 5\% damping, the maximum relative displacement is about $0.1 \mathrm{~m}$. for one meter width of wall panel, the ultimate shear force $\left(\mathrm{V}_{\mathrm{u}}\right)$ and the ultimate moment $\left(\mathrm{M}_{\mathrm{u}}\right)$ are $18.4 \mathrm{kN}$ and $27.6 \mathrm{kN}-\mathrm{m}$ respectively. The reduced nominal shear capacity of the section $\left(\phi \mathrm{V}_{\mathrm{n}}=46.7 \mathrm{kN}\right)$ is satisfactory, while, the reduced nominal moment capacity $\left(\phi \mathrm{M}_{\mathrm{n}}=9.35 \mathrm{kN}-\mathrm{m}\right)$ is not satisfactory. Therefore, lateral walls alone are not capable of resisting lateral loads produced by low intensity earthquake or by slow wind speeds. Table 2 presents values for the natural frequency, horizontal displacement, shear and moment for different number of floors using suggested 3-DS and using skeleton system. It can be noticed that the natural frequencies for the 3-DS are much larger than these for 
Table 2: Calculated natural frequency, horizontal displacement, shear, and moment for different numbers for floors constructed using suggested panel system (Case C), (3DS), and Skelton system, (SK).

\begin{tabular}{|c|c|c|c|c|c|c|c|c|c|}
\hline \multirow[b]{2}{*}{ Floor } & \multirow[b]{2}{*}{ No } & \multicolumn{2}{|c|}{$\omega($ radians/sec $)$} & \multicolumn{2}{|c|}{$\mathbf{U}(\mathbf{m})$} & \multicolumn{2}{|c|}{$\mathrm{V}(\mathrm{kN})$} & \multicolumn{2}{|c|}{ M (kN-m) } \\
\hline & & 3DS & SK & 3DS & SK & 3DS & SK & 3DS & SK \\
\hline 1 & 1 & 353.37 & 24.91 & $0.91 E-5$ & 0.01254 & 14.41 & 109.48 & 21.61 & 164.22 \\
\hline 3 & $\begin{array}{l}1 \\
2 \\
3\end{array}$ & $\begin{array}{r}150.92 \\
417.24 \\
590.94\end{array}$ & $\begin{array}{l}10.636 \\
29.406 \\
41.649\end{array}$ & $\begin{array}{c}0.66 E-4 \\
0.12 E-3 \\
0.15 E-3\end{array}$ & $\begin{array}{l}0.0406 \\
0.0721 \\
0.0882\end{array}$ & $\begin{array}{l}104.4 \\
81.78 \\
41.65\end{array}$ & $\begin{array}{l}354.24 \\
277.14 \\
144.54\end{array}$ & $\begin{array}{l}156.6 \\
122.67 \\
62.48\end{array}$ & $\begin{array}{l}531.71 \\
415.71 \\
216.81\end{array}$ \\
\hline $\begin{array}{l}7 \\
\text { Single }\end{array}$ & $\begin{array}{l}1 \\
2 \\
3 \\
4 \\
5 \\
6 \\
7\end{array}$ & $\begin{array}{l}69.275 \\
204.52 \\
330.41 \\
440.04 \\
529.71 \\
595.57 \\
635.61\end{array}$ & $\begin{array}{l}4.882 \\
14.414 \\
23.261 \\
31.013 \\
37.333 \\
41.975 \\
44.797\end{array}$ & $\begin{array}{c}0.26 E-3 \\
0.52 E-3 \\
0.74 E-3 \\
0.94 E-3 \\
0.00108 \\
0.00119 \\
0.00124\end{array}$ & $\begin{array}{l}0.0307 \\
0.0584 \\
0.08202 \\
0.10167 \\
0.1175 \\
0.1289 \\
0.1346\end{array}$ & $\begin{array}{l}413.7 \\
394.54 \\
357.53 \\
304.60 \\
238.04 \\
160.60 \\
75.3\end{array}$ & $\begin{array}{l}268.08 \\
244.4 \\
216.84 \\
194.42 \\
171.8 \\
134.08 \\
72.29\end{array}$ & $\begin{array}{r}620.55 \\
591.81 \\
536.28 \\
456.89 \\
357.09 \\
240.86 \\
112.90\end{array}$ & $\begin{array}{l}402.12 \\
366.61 \\
325.26 \\
291.64 \\
257.71 \\
201.11 \\
108.43\end{array}$ \\
\hline $\begin{array}{l}7 \\
\text { Double* }\end{array}$ & $\begin{array}{l}1 \\
2 \\
3 \\
4 \\
5 \\
6 \\
7\end{array}$ & $\begin{array}{l}85.88 \\
232.62 \\
364.1 \\
498.14 \\
597.17 \\
643.73 \\
837.68\end{array}$ & & $\begin{array}{c}0.12 E-3 \\
0.24 E-3 \\
0.35 E-3 \\
0.54 E-3 \\
0.69 E-3 \\
0.80 E-3 \\
0.85 E-3\end{array}$ & & \begin{tabular}{r|}
380.35 \\
366.21 \\
340.01 \\
301.23 \\
242.85 \\
167.31 \\
79.12
\end{tabular} & & $\begin{array}{l}570.4 \\
549.8 \\
509.9 \\
452.3 \\
364.5 \\
251.0 \\
119.0\end{array}$ & \\
\hline
\end{tabular}

*: The first three floors are constructed using double panels; $\omega$ : natural frequency; U: deflection; V: external Shear; M: external moment.

horizontal displacement response to El-Centro earthquake of the 3-DS is much less than that of the skeleton system. For instance the seventh floor horizontal displacement of the 3-D double panel system (the lower three floors are constructed with double panel walls) is $0.85 \mathrm{~mm}(1.24 \mathrm{~mm}$ for the single panel walls for the lower three floors), while it is $134.6 \mathrm{~mm}$ for the seventh floor of the skeleton system. The shear and bending moment capacity of the walls in the 3-DS one and the three story buildings are satisfactory using single panels. However, the single panel walls are not satisfactory for the seven-story building and the walls of the lower three stories should be constructed of double panels so that the building is capable of resisting moderate-to-high intensity earthquake. In this case and for $3 \mathrm{~m}$ effective length of wall, the ultimate shear and the ultimate moment at the base of the first story of the seven story building are: $\mathrm{V}_{\mathrm{u}}=1.1 \mathrm{x}$ $1.3 \times 380.35=544 \mathrm{kN}, \mathrm{M}_{\mathrm{u}}=1.1 \times 1.3 \times 570.4=817 \mathrm{kN}-\mathrm{m}$, where $1.1,1.3$ are the axial and lateral load factors respectively. It should be noted here that the values in 
table 2 resulted from applied service load. The reduced shear and moment capacities are $\left(\phi \mathrm{V}_{\mathrm{n}}=580 \mathrm{kN}\right)$ and $\left(\phi \mathrm{M}_{\mathrm{n}}=980 \mathrm{kN}-\mathrm{m}\right)$ respectively. The shear and moment values for one column of the skeleton system are: $V_{u}=383 \mathrm{kN}$, $\mathrm{Mu}=575 \mathrm{kN}-\mathrm{m}, \phi \mathrm{V}_{\mathrm{n}}=200 \mathrm{kN}$ and $\phi \mathrm{M}_{\mathrm{n}}=60 \mathrm{kN}-\mathrm{m}$ which clearly indicates that the columns provided are not adequate to resist lateral loads produced by low intensity earthquake or by slow wind. It is also clear in this table that the 3DS is superior to the skeleton system in resisting lateral loads.

Table 3: $\quad$ Ceiling and wall panel specimens subjected to static loading.

\begin{tabular}{|c|c|c|c|c|c|c|c|}
\hline \multirow[t]{2}{*}{ Panel } & \multirow[t]{2}{*}{ Name } & \multirow[t]{2}{*}{ No. } & \multicolumn{3}{|c|}{ Dimensions (cm) } & \multirow[b]{2}{*}{$\boldsymbol{h}$} & \multirow{2}{*}{$\begin{array}{l}P_{\max } \\
(\mathbf{k N}) \\
\end{array}$} \\
\hline & & & $\mathbf{a}$ & $l$ & b & & \\
\hline \multirow[t]{6}{*}{ Ceiling } & C1B28 & 1 & 35 & 105 & 36 & 20 & 17 \\
\hline & C2B28 & 2 & 34 & 102 & 35 & 20 & 23 \\
\hline & C3B28 & 3 & 34 & 102 & 36 & 20 & 22 \\
\hline & C4B28 & 4 & 36 & 108 & 56 & 20 & 33 \\
\hline & C5B28 & 5 & 36 & 108 & 56 & 20 & 31 \\
\hline & C5B28 & 6 & 35 & 105 & 57 & 20 & 32 \\
\hline \multirow[t]{17}{*}{ Wall } & W1B7 & 1 & 30 & 90 & 40 & 18 & 12 \\
\hline & W2B7 & 2 & 30 & 90 & 40 & 18 & 13 \\
\hline & W3B7 & 3 & 30 & 87 & 40 & 18 & 13 \\
\hline & W4B28 & 4 & 30 & 87 & 40 & 18 & 17.5 \\
\hline & W5B28 & 5 & 30 & 87 & 40 & 18 & 18 \\
\hline & W6B28 & 6 & 29 & 87 & 40 & 18 & 17 \\
\hline & W7F28 & 7 & 29 & 87 & 18 & 40 & 135 \\
\hline & W8F28 & 8 & 29 & 87 & 18 & 40 & 132 \\
\hline & W9F28 & 9 & 29 & 87 & 18 & 40 & 123 \\
\hline & W1S & 1 & 30 & 60 & 18 & 18 & \multirow{8}{*}{$\begin{array}{l}32.5 \\
21 \\
22.5\end{array}$} \\
\hline & W2S & 2 & 30 & 60 & 18 & 18 & \\
\hline & W3S & 3 & 30 & 60 & 18 & 18 & \\
\hline & & & e & $\mathbf{b}$ & $\mathbf{t}$ & h & \\
\hline & W1V & 1 & 0 & 40 & 17 & 96 & \\
\hline & W2V & 2 & 0 & 38 & 17 & 98 & \\
\hline & W3V & 3 & 0 & 40 & 17 & 98 & \\
\hline & W1VE & 1 & 0.275 & 120 & 18 & 280 & \\
\hline
\end{tabular}

C: Ceiling; W: Wall; B: Beam Element; F: Two points loading on shear wall element;

S: One Point Loading on shear wall element; V: Axial distributed loading on shear wall element;

VE: Axial loading on shear wall element with eccentricity; 7: seven days of curing; 28: twenty eight days of curing.

Table 3 presents experimental flexural results for ceiling and wall panels in addition to experimental axial compression results for wall panels (Fig. 3). The load-deflection diagrams, obtained for different wall and ceiling panels, showed typical elasto-plastic behavior, which was demonstrated in linear behavior up 
until the yielding point of reinforcing steel before became nonlinear up to failure load. The maximum transverse load $\left(\mathrm{P}_{\max }\right)$ for beam specimens was for ceiling panels C4B28, C5B28, and C6B28 at about $32 \mathrm{kN}$ with corresponding shear and moment of $17.14 \mathrm{kN}$ and $6.17 \mathrm{kN}-\mathrm{m}$, respectively. The nominal shear and moment capacities are $43 \mathrm{kN}$ and $5.8 \mathrm{kN}-\mathrm{m}$, respectively. It is clear that the moment at failure is slightly higher than the nominal moment capacity of the beam, while the shear at failure is much less than the shear capacity of the beam. Therefore the failure is due to bending, since the moment capacity is exceeded. The maximum experimental axial compression load for each of wall panel specimen $\mathrm{W} 2 \mathrm{~V}$ and $\mathrm{W} 3 \mathrm{~V}$ is about $300 \mathrm{kN}$, while the nominal axial load capacity of the wall is $\left(\mathrm{P}_{\mathrm{n}}=380 \mathrm{kN}\right)$. The failure at a lower value can be attributed to that the concrete layers are thin or having large slenderness ratio at one hand and the ability to behave as a composite section on the other hand.
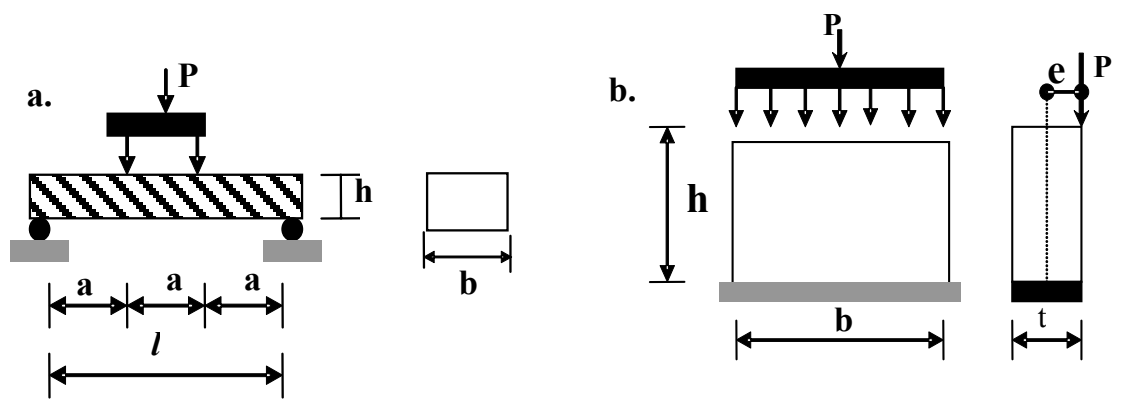

Figure 3: $\quad$ Experimental set up for (a) simply supported beam, (b) wall panel.

\section{References}

[1] Nilson, A. H. Design of concrete structures, $12^{\text {th }}$ edition, McGraw-Hill, Singapore, 1997.

[2] Benayoune, A., Samad A. A. \& Trikha, D.N., Abang, A. A., Ashrabov, A. A., Structural behavior of eccentrically loaded precast panels. Construction and Building Materials, 20 (9), pp. 713-724, 2006.

[3] Benayoune, A., Samad, A. A., Abang, A. A. \& Trikha, D. N., Response of pre-cast reinforced composite sandwich panels to axial loading. Construction and Building Materials, 21(3), pp. 677-685, 2007.

[4] Lan, S., Lok, T.-S. \& Heng, L., Composite structural panels subjected to explosive loading. Construction and Building Materials, 19 (7), pp. 387-395, 2005.

[5] Mo, Y.L. \& Chan J., Behavior of reinforced-concrete-framed shear walls. Nuclear Engineering and Design, 55 (1), pp. 55-68, 1996.

[6] Paulay T. \& Priesley M. J., Seismic design of reinforced concrete and masonry Buildings, Wiley, New York, 1992. 
42 Earthquake Resistant Engineering Structures VI

[7] Nilson, A. H., Design of prestressed concrete, $2^{\text {nd }}$ edition, John Wiley \& Sons Inc., Canada, 1987.

[8] ACI Committee 318, "Building Code Requirements for Structural Concrete (ACI 318M-05)," American Concrete Institute, Farmington Hills, Mich., USA, 2005.

[9] ASTM Book of Standards, "Construction: Concrete and Aggregates (V. 0405)," American Society for Testing Materials, Ann Arbor, MI, USA, 2005. 